\title{
Enzyme assays in the management of pregnancy
}

\author{
PETER CURZEN \\ From the Obstetric Unit, Westminster Medical School, Queen Mary's Hospital, London, SWI5
}

The occurrence of increased serum enzyme activity in patients with diseases involving tissue damage such as myocardial infarcation suggested that placental damage may also give rise to characteristic changes in maternal serum enzymes, which might be useful diagnostically.

One of the problems in obstetrics is the recognition of placental 'dysfunction' or 'insufficiency', terms which are used by obstetricians to indicate a process of impaired transmission of nutrients resulting in retarded fetal growth, and progressing eventually to impaired oxygen transfer resulting in fetal hypoxia and possibly death from anoxia.

The diagnosis depends on the demonstration of fetal distress during labour, or on the delivery of a baby with a low Apgar ${ }^{1}$ score, or a birth weight below the 10th centile for that duration of pregnancy. These criteria have only recently been applied to the evaluation of tests of placental function.

It has been established that a number of enzymes in maternal serum remain unchanged in normal pregnancy, but that others increase either during normal or abnormal pregnancy or in both (Table I).

Serum enzymes which do not change during normal pregnancy are cholinesterase (EC 3.1.1.8) (Meade and Rosalki, 1963; Rimbach and Figge, 1966), 2-hydroxybutyrate dehydrogenase (EC 1.1. 1.27) (Meade and Rosalki, 1963), and alanine and aspartate aminotransferases (EC 2.6.1.2.4.2.6.1.1) (Meade and Rosalki, 1963; Szekely and Fritzsh, 1969). Studies of lactate dehydrogenase (EC 1.1.1.27) and isocitrate dehydrogenase (EC 1.1.1.42) have given less uniform results. Whereas most authors have found them to remain unchanged, an increase in lactate dehydrogenase at term was found by Pulkkinen and Willman (1968) and a marked increase in isocitrate dehydrogenase was found at 39-40 weeks by Kraussold (1969).

Serum $\beta$-glucuronidase (EC 3.2.1.31), hyaluronidase (EC 3.2.1.35) and $\beta$-acetylglucosaminidase (EC 3.2.1.30) have all been described as increasing late in normal pregnancy (Platt and Platt, 1968).

${ }^{1}$ The Apgar score is based on assessment of the baby's colour, heart rate, respirations, muscle tone, and the response to a catheter in the nostril. The best prognosis is indicated by a score of 10 and the worst by a score of 0 .
In abnormal pregnancy, many of the above enzymes have been found to increase. Thus increased. levels of both aminotransferases were found in two out of 14 patients with mild pre-eclampsia, and 1 t out of 12 with eclampsia (Dass and Bhagwani, 1964) These results were taken to mean that toxaemia is associated with liver damage, and it was suggested that estimations of serum aminotransferases might be of prognostic value in toxaemia. Similarly iso citrate dehydrogenase may show transient increases in pre-eclampsia or accidental haemorrhage (Jeacock $\overrightarrow{2}$ Morris, and Plester, 1962; Meade and Rosalkip 1963; Pulkkinen and Willman, 1968), possibly due to placental infarction (Dawkins and Wigglesworth 1961). Pulkkinen and Willman (1968) also found increased levels of lactate dehydrogenase in fous patients with hypertension.

Plasma renin (EC 3.4.4.15) levels were found to increased during the third trimester in nine normas women (Geehoed and Vander, 1968), but the mea value at 13-27 weeks in 10 women who subsequentl蛋 developed toxaemia was greater than that in 48 i⿱ whom pregnancy remained uneventful.

None of the above enzymes has been used to assis in the management of pregnancy. However, diamine oxidase (EC 1.4.3.6.), 'oxytocinase', and the heat? stable isoenzyme of alkaline phosphatase (EC 3.1.3.1 all of which increase during normal pregnancy, have been found useful in the management of pregnancy. and will be discussed in greater detail.

\section{Diamine Oxidase}

Southren and Weingold (1966), Southren, Kobayash Weingold, and Carmody (1966), and Southren?: Weingold, Kobayashi, Sherman, Grimaldi, anf Gold (1968) studied the serum levels of diaminis oxidase, using putrescine labelled with isotope as the substrate. They showed that there is a fairly rapi@ increase in activity during the first trimester, followed by a rather slower rise during the rest of the pregnancy, with a wide range of values. The outcom of pregnancies complicated by threatened abortion, by a history of habitual abortion, or missed abortiof appeared to be related to the serial changes 


\begin{tabular}{lll}
\hline Enzyme & Normal Pregnancy & Abnormal Pregnancy \\
\hline Alanine aminotransferase & No change & May increase \\
Aspartate aminotransferase & No change & May increase \\
Alkaline phosphatase (heat-stable) & Increased & May increase further or decrease \\
B-acetylglucosaminidase & Increased & - \\
Cholinesterase & No change & May fall \\
Diamine oxidase & Increased & - \\
B-glucuronidase & Increased & - \\
Hyaluronidase & Increased & - \\
2-Hydroxybutyrate dehydrogenase & No change & May increase \\
Isocitrate dehydrogenase & No change & May increase \\
Lactate dehydrogenase & No change & May increase further or decrease \\
Oxytocinase & Increased & May increase further \\
Renin & Increased & \\
\hline
\end{tabular}

Table I Changes in maternal serum enzymes during normal and abnormal pregnancy

diamine oxidase levels. When the levels increased steadily and remained within the normal range, the pregnancy continued into the third trimester. Conversely, a falling or persistently low level was associated with a significant increase in fetal wastage, although some did continue to term. In cases of pregnancy complicated by diabetes the abnormality of enzyme levels appeared to be related to the severity of the diabetes, but the relationship to fetal survival was poor. In 16 pregnancies complicated by hydatifiform mole, serial diamine oxidase levels remained within the normal range during the first trimester, but fell to zero during the second trimester (Torok, Brewer, and Dolkart, 1970). The same authors were unable to detect any diamine oxidase in the serum of 71 out of 80 other patients with trophoblastic disease. Resnik and Levine (1969) confirmed that diamine oxidase activity rises rapidly during the first trimester, and remains elevated during the second and third trimesters; however in 30 patients with 'high risk' pregnancies they were unable to predict the outcome by means of serial assays.

\section{'Oxytocinase'}

'Oxytocinase' was first described by Fekete (1930) as an enzyme present in the plasma of pregnant women, which hydrolysed oxytocin and which was measured by the biological assay of the unhydrolysed hormone. Recently, Kleiner (1969) reviewed the evidence that 'oxytocinase' is an exopeptidase and discussed the different substrates which have formed the basis of its biochemical assay. He also reviewed the histochemical and biochemical evidence showing that the placenta is the main source of this enzyme. Many workers have studied 'oxytocinase' in the maternal serum during normal and abnormal pregnancies, using various substrates to assay the enzyme, such as L-leucyl- $\beta$-naphthylamide (Kleiner, 1969 ; Kleiner, Brouet-Yager, and Graff, 1969), leucine-p-nitroanilide (Rimbach and Schreiner, 1967), or Lcystine-di- $\beta$-naphthylamide (Babuna and Yenen, 1966a and b; Klimek, 1969; Poch, Abad Martinez, Holzer, and Hohlweg, 1970; Hensleigh and Krantz, 1970). There is universal agreement, regardless of the substrate used, that serum levels of this enzyme increase during normal pregnancy from the second trimester onwards, showing a fairly wide scatter. There is some evidence that serum oxytocinase levels may be related to the duration of pregnancy; thus, Lambrinopoulos (1964) found significantly higher levels in patients who were seven to 19 days past term than in controls at term. They may also be related to the duration of labour, for abnormally high levels have been found in uterine inertia (Babuna and Yenen, 1966a). High levels have also been found in twin pregnancies (Ichaliotis and Lambrinopoulos, 1965; Babuna and Yenen, 1966a), though this was not confirmed by Kleiner et al (1969). Serum oxytocinase levels have also been shown to correlate with placental weight (Klimek, 1969; Poch et al, 1970), fetal weight (Poch et al, 1970), and fetal surface area (Klimek, 1969).

The value of serum oxytocinase assays in the diagnosis of placental dysfunction is difficult to assess, since the latter is defined differently by different workers. Babuna and Yenen (1966) claimed that rising serum enzyme levels were usually a good sign indicating a favourable prognosis, whilst falling levels suggested either the imminent onset of labour or intrauterine death of the fetus. In a retrospective analysis of pregnancies grouped according to the state of the fetus at birth, Klimek (1969) found the mean value to be highest in the group with babies in good condition on delivery, lowest in the group with stillborn babies, and intermediate in the group with babies in poor condition at birth. However, in all groups there was fairly wide variation about the mean values. Similarly Kleiner et al (1969) found the mean enzyme level in 50 pregnancies ending in the birth of a dysmature baby' to be significantly lower than that for a control

${ }^{1}$ One whose birth weight is more than two standard deviations below the mean weight for the duration of pregnancy. 
group, but in only 18 were the levels below the lower limit of normal, so that only in this small group could the enzyme assay have been used to 'predict' that the baby would be born dysmature.

Hensleigh and Krantz (1970) estimated serum 'cystine aminopeptidase ${ }^{1}$ ' in a heterogeneous group of 186 pregnant women with a variety of clinical abnormalities including hypertension, pre-eclampsia, and a bad obstetric history such as a previous stillbirth. Twelve patients had abnormal serum levels and all showed acceptable evidence of inadequate placental function. In 174 patients the levels were normal, but seven of these also showed evidence of placental dysfunction. Thus, although no false positives were encountered there were seven false negatives, which the authors attributed to the lack of serial samples in these cases.

This review of the literature on oxytocinase leads to the conclusion that when serial assays of the enzyme are performed, a progressive rise of activity suggests that the pregnancy is likely to continue and the fetus is probably not at risk. Falling or abnormally low levels suggest either that the fetus is at risk, or that the spontaneous onset of labour is imminent.

\section{Heat-stable Alkaline Phosphatase}

Since Coryn (1934) first reported that maternal serum alkaline phosphatase is raised in late pregnancy, there have been numerous confirmatory reports including our own (Curzen and Morris, 1965). There is also considerable evidence that the placental content of alkaline phosphatase increases in late pregnancy and that it is relatively higher in pregnancy complicated by hypertensive disorders than in normal pregnancy (Jeacock, Morris, and Plester, 1963; Curzen, 1964 and 1967). This led to the suggestion that some of the increase in the serum alkaline phosphatase might be due to a placental component, and that the assay of this placental isoenzyme might be of clinical use. The discovery by Neale, Clubb, Hotchkis, and Posen (1964) that the placental isoenzyme is relatively heat-stable, and the demonstration by McMaster, Tennant, Clubb, and Neale (1964) that incubation of serum at $56^{\circ} \mathrm{C}$ for 30 minutes destroys most of the alkaline phosphatase from non-placental sources, provided a simple means of separating the placental isoenzyme. We studied serum heat-stable alkaline phosphatase (HSAP) levels in normal pregnancy, and found a fairly wide range of values, but with a progressive rise of mean values during the last twelve weeks of pregnancy (Curzen and Morris, 1966, 1968). Furthermore, HSAP levels tend to be abnormally

'Oxytocinase' estimated with cystine-di- $\beta$-naphthylamide as substrate. high in patients suffering from hypertensive dis- $\frac{\rho}{\overline{5}}$ orders of pregnancy, and there appears to be a 0 relationship between the severity of the hyper- $\vec{F}$ tensive disorder and the extent to which serum HSAP levels are deranged. Hunter (1969) showed that $\vec{F}$ incubating serum at $65^{\circ} \mathrm{C}$ for 30 minutes instead of $\stackrel{\text { ? }}{\circ}$ $56^{\circ} \mathrm{C}$ entirely inactivated all non-placental iso-을 enzymes of alkaline phosphatase. Using this method $\frac{\bar{c}}{\bar{s}}$ he showed that serial HSAP estimations underwent $\frac{\sqrt{\sigma}}{\widetilde{\sigma}}$ an abnormal rise in patients with pre-eclampsia. $\supseteq$ Furthermore, the abnormal elevation of HSAP seemed to precede the onset of clinical signs by two $\vec{\circ}$ to three weeks. Several workers have suggested that:serial HSAP determinations may sometimes provide $\vec{\omega}$ an indication of placental dysfunction and fetal prognosis (Curzen and Morris, 1966, 1968; Messer,? 1967; Hunter, 1969).

However, Watney, Hallu, Ladell, and Scott (1970) have shown that in a group of 29 patients.whose babies had grossly abnormal placentae and $\mathscr{\varrho}$ weighed less than the 10 th centile at birth, only $34 \%$ had abnormally high or low HSAP values inpregnancy compared with $83 \%$ who had abnormally low oestriol values. Furthermore these workers heated their sera at $56^{\circ} \mathrm{C}$ for 30 minutes before measuring HSAP activity, and therefore may not have completely inactivated non-placental isoenzymes.

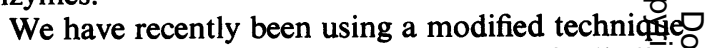
for assaying the placental isoenzyme of alkal hises phosphatase. This is based on the extensive in $-\bar{O}$ vestigations of Fishman and his colleagues into the biochemical characteristics of the isoenzymes of alkaline phosphatase (Fishman and Ghosh, $1967 \stackrel{2}{7}$ Fishman, Inglis, Green, Anstiss, Ghosh, Reiff 3 Rustigan, Krant, and Stolbaga, 1968a; Fishman, Inglis, and Ghosh, 1968b; Ghosh and Fishman? 1967). They have shown that incubating serum at: $65^{\circ} \mathrm{C}$ for five minutes totally inactivates all isoenzymes? other than those from the placenta, and also that the optimum $p \mathrm{H}$ and substrate concentration are highe for the placental isoenzymes than for other iso enzymes. We have therefore assayed the alkaline phosphatase activity remaining after heating the serum at $65^{\circ} \mathrm{C}$ for five minutes.

Using this method we determined the normat. range of serum HISAP during the last 12 weeks of pregnancy on 204 samples from normal pregnant women (Fig. 1). Assays were also carried out in 50 pregnant women thought to be at risk from placentad dysfunction. The clinical diagnoses in the latter are detailed in Table II. Each of these patients had simultaneous assays of serum HSAP and 24-hou㑋 urinary total oestrogens (Oakey, Bradshaw, Eccles,? Stitch, and Heys, 1967) performed two or three times a week until delivery. Serum HSAP result 


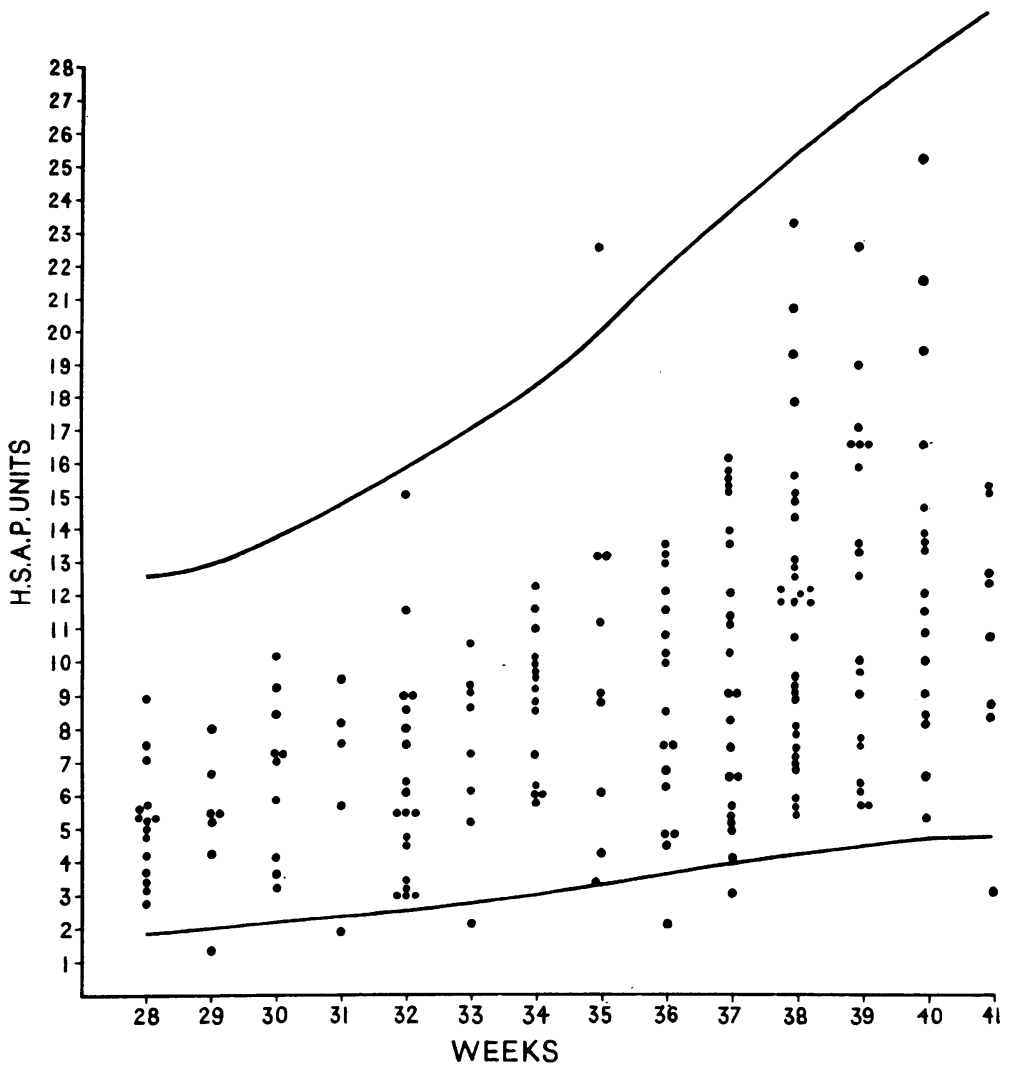

Fig. 1 The normal range of serum HSAP during the last 12 weeks of pregnancy. The lines indicate $95 \%$ confidence limits. The HSAP unit = the amount of enzyme which will liberate $1 \mathrm{mg}$ phenol from $36 \mathrm{mM}$ disodium phenylphosphate in 15 minutes at $37^{\circ} \mathrm{C}$ and in bicarbonate buffer at $\mathrm{pH} 10 \cdot 7$.

\begin{tabular}{ll}
\hline Diagnosis & Number of Patients \\
\hline Pre-eclampsia & 26 \\
Hypertension & 12 \\
'Small-for-dates' & 10 \\
Albuminuria & 1 \\
Twins & 1 \\
\hline
\end{tabular}

Table II Clinical diagnosis in patients in whom serum heat-stable alkaline phosphatase was estimated because of the possibility of placental dysfunction

were considered abnormal when they were above or below the limits of normal, or when two successive determinations showed a reduction in activity even though they were within normal limits.

Normal and abnormal results were related to birth weight (Table III), objective signs of fetal distress, ie, a fetal blood $p \mathbf{H}$ of less than $7 \cdot 2$, or delayed onset of fetal bradycardia (Table IV), and the Apgar score at one minute (Table V). From these results it can be seen that serial total urinary oestrogen determinations correctly predicted fetal dysmaturity in $64.7 \%$ of cases $(P=<0.001)$, fetal distress in $64.3 \%$ of cases $(\mathrm{P}=<0.001)$, and a poor Apgar score in $61.5 \%$ of cases $(\mathrm{P}=<0.01)$. In contrast, serum HSAP determinations were of little value in this respect.

The correlation of serum HSAP levels and urinary oestrogen output was poor $(r=0.13, \mathrm{SE}=0.06)$; the correlation of serum HSAP or urinary oestrogen output with either birth weight or placental weight was even worse $(r \neq 0 \cdot 14)$.

These results indicate that serial assays of serum HSAP are of no value for determining fetal prognosis, even when great care is taken to assay only the placental isoenzyme. It may be that abnormally high serum HSAP levels represent placental damage, and that abnormally low levels indicate poor placental development. However, there does not seem to be any strong evidence to support this idea at the present time. It is perhaps of interest to note that serial estimations of urinary total oestrogen output were also associated with a fairly high incidence of inaccurate predictions of the outcome of pregnancy.

The conclusion seems to be that assays of single enzymes are of little value in the management of pregnancy; however, assays of several enzymes may prove to be more useful. 


\begin{tabular}{|c|c|c|c|c|c|}
\hline \multirow[t]{2}{*}{ Birth Weight } & \multirow[t]{2}{*}{ No. of Cases } & \multicolumn{2}{|l|}{ Serum HSAP } & \multirow{2}{*}{$\begin{array}{l}\text { Urinary Oestrogen } \\
\text { Normal }\end{array}$} & \multirow[b]{2}{*}{ Abnormal } \\
\hline & & Normal & Abnormal $^{1}$ & & \\
\hline $\begin{array}{l}<10 \text { th percentile } \\
>10 \text { th percentile }\end{array}$ & $\begin{array}{l}17 \\
33\end{array}$ & $\begin{array}{l}15(88 \cdot 2 \%) \\
28(84.8 \%)\end{array}$ & $\begin{array}{l}2(11 \cdot 8 \%) \\
5(15 \cdot 2 \%)\end{array}$ & $\begin{array}{r}6(35 \cdot 3 \%) \\
28(84 \cdot 8 \%)\end{array}$ & $\begin{array}{r}11(64 \cdot 7 \%) \\
5(15 \cdot 2 \%)\end{array}$ \\
\hline Total & 50 & $\begin{array}{l}43(86 \%) \\
x^{2}=0.01, p\end{array}$ & $0.9^{7(14 \%)}$ & $\begin{array}{l}34(68 \%) \\
x^{2}=15.04, p<0 .\end{array}$ & $16(32 \%)$ \\
\hline
\end{tabular}

\begin{tabular}{|c|c|c|c|c|c|}
\hline & \multirow[t]{2}{*}{ No. of Cases } & \multicolumn{2}{|c|}{ Serum HSAP } & \multicolumn{2}{|c|}{ Urinary Oestrogen } \\
\hline & & Normal & Abnormal $^{1}$ & Normal & Abnormal \\
\hline $\begin{array}{l}\text { Fetal distress } \\
\text { No fetal distress }\end{array}$ & $\begin{array}{l}14 \\
36\end{array}$ & $\begin{array}{l}12(85 \cdot 7 \%) \\
31(86 \cdot 1 \%)\end{array}$ & $\begin{array}{l}2(14.3 \%) \\
5(13.9 \%)\end{array}$ & $\begin{array}{r}5(35 \cdot 7 \%) \\
29(80 \cdot 1 \%)\end{array}$ & $\begin{array}{l}9(64 \cdot 3 \%) \\
7(19 \cdot 4 \%)\end{array}$ \\
\hline Total & 50 & $\begin{array}{l}43(86 \%) \\
x^{2} \quad 0 \cdot 24,\end{array}$ & $7(14 \%)$ & $\begin{array}{l}34(68 \%) \\
x^{2}=11.49\end{array}$ & $16(32 \%)$ \\
\hline
\end{tabular}

Table IV Abnormalities of maternal heat-stable alkaline phosphatase $(H S A P)$ and urinary oestrogen output according to the presence or absence of fetal distress

'Usually high, but sometimes low

\begin{tabular}{|c|c|c|c|c|c|c|}
\hline & \multirow[t]{2}{*}{ No. of Cases } & \multicolumn{2}{|c|}{ Serum HSAP } & \multicolumn{3}{|c|}{ Urinary Oestrogen } \\
\hline & & Normal & Abnormal ${ }^{1}$ & Normal & Abnormal & \\
\hline $\begin{array}{l}\text { Apgar }(0-5) \\
\text { Apgar }(6-10)\end{array}$ & $\begin{array}{l}13 \\
37\end{array}$ & $\begin{array}{l}13(100 \%) \\
30(81 \cdot 1 \%)\end{array}$ & $\begin{array}{l}0 \\
7(18.9 \%)\end{array}$ & $\begin{array}{r}5(38.5 \%) \\
29(78.4 \%)\end{array}$ & $\begin{array}{l}8(61.5 \%) \\
8(21.6 \%)\end{array}$ & \\
\hline Total & 50 & $43(86 \%)$ & $7(14 \%)$ & $\begin{array}{l}34(68 \%) \\
\chi^{2}=9 \cdot 0, p\end{array}$ & $16(32 \%)$ & 을 \\
\hline
\end{tabular}

Table $\mathrm{V}$ Abnormalities of maternal heat-stable alkaline phosphatase and urinary oestrogen output according tacे Apgar score of a newborn infant

${ }^{1}$ Usually high, but sometimes low.

This work was supported by a grant from the Medical Research Council. It is a pleasure to acknowledge the help of Miss Helen Hensel who performed the biochemical assays, and Dr D. F. Hawkins of the Institute of Obstetrics and Gynaecology, who calculated the approximate fiducial limits for Figure 1.

\section{References}

Babuna, C., and Yenen, E. (1966a). Further studies on serum oxytocinase in pathologic pregnancy. Amer. J. Obstet. Gynec., 94, 868-875.

Babuna, C., and Yenen, E. (1966b). Enzymatic determination of placental function. Amer. J. Obstet. Gynec., 95, 925-934.

Coryn, G. (1934). Les phosphatases du sang dans le diagnostic des affections osseuses. J. Chir. (Brux.), 33, 213-224.

Curzen, P. (1964). Variations in the enzyme histochemistry of the placenta. J. Obstet. Gynaec. Brit. Cwlth, 71, 388-399.

Curzen, P., and Morris, I. (1965). Serum alkaline phosphatase in the hypertensive disorders of pregnancy. J. Obstet. Gynaec. Brit. Cwlth., 72, 397-401.

Curzen, P., and Morris, I. (1966). Serum heat-stable alkaline phosphatase in the hypertensive disorders of pregnancy. J. Obstet Gynaec. Brit. Cwlth., 73, 640-646.

Curzen, P., and Morris, I. (1968). Heat-stable alkaline phosphatase in maternal serum. J. Obstet. Gynaec. Brit. Cwlth., 75, 151-157.

Dass, A., and Bhagwanani, S. (1964). Serum transaminases in toxaemia of pregnancy. J. Obstet. Gynaec. Brit. Cwlth., 71, 727-739.
Dawkins, M. J. R., and Wigglesworth, J. S. (1961). Serum isocitrie dehydrogenase in normal and abnormal pregnancy. J. Obste Gynaec. Brit. Cwlth., 68, 264-269.

Fekete, K. (1930). Beiträge zur Physiologie der Gravidität. Endo krinologie, 7, 364-369.

Fishman, W. H., and Ghosh, N. K. (1967). Isoenzymes of human. alkaline phosphatase. Advanc. clin. Chem., 10, 255-370.

Fishman, W. H., Inglis, N. R., and Ghosh, N. K. (1968a). Distinctionf between intestinal and placental isoenzymes of alkaline phosphatase. Clin. chim. Acta., 19, 71-79.

Fishman, W. H., Inglis, N. R., Green, S., Anstiss, C. L., Ghosh, N. Kঙ․․ Reif, A. E., Rustigian, R., Krant, M. J., and Stolbach, L. I尺́ (1968b). Immunology and biochemistry of regan isoenzyme of alkaline phosphatase in human cancer. Nature (Lond.), 219, 697-699.

Geelhoed, G. W., and Vander, A. J. (1968). Plasma renin activities during pregnancy and parturition. J. clin. Endocr., 28, 412-415

Ghosh, N. K., and Fishman, W. H. (1967). Characterisation of huma? placental alkaline phosphatase isoenzymes. Fed. Proc., 26, 558 .

Gordon, R. D., Parsons, S., and Symonds, E. M. (1969). A prospective study of plasma-renin activity in normal and toxaemic pregs nancy. Lancet, 1, 347-349.

Hensleigh, P. A., and Krantz, K. E. (1970). Oxytocinase and placent dob function. Amer. J. Obstet. Gynec., 107, 1233-1240.

Hunter, R. J. (1969). Serum heat stable alkaline phosphatase: index of placental function. J. Obstet. Gynaec. Brit. Cwlth., 7@ 1057-1069.

Ichaliotis, S., and Lambrinopoulos, T. C. (1965). Serum oxytocinase io twin pregnancy. Obstet. and Gynec., 25, 270-272.

Jeacock, M. K., Morris, N. F., and Plester, J. A. (1962). Serum isor citric dehydrogenase activity during pregnancy. J. Obste $\overline{0}$ Gynaec. Brit. Cwlth., 69, 74-80. 
Jeacock, M. K., Morris, N. F., and Plester, J. A. (1963). The activity of alkaline and acid phosphatase in the human placenta. $J$. Obstet. Gynaec. Brit. Cwlth., 70, 267-273.

Kleiner, H. (1969). Serum L-leucyl- $\beta$-napthylamide hydrolase (LNAse) activity in normal human pregnancy and in pregnancy associated with foetal dysmaturity. In The Foeta-Placental Unit, edited by A. Pecile. Excerpta Medica Foundation, Amsterdam. pp. 363-368.

Kleiner, H., Brouet-Yager, M., and Graff, G. (1969). Serum L-Leucyl$\beta$-Naphthylamide hydrolase activity in normal single and twin human pregnancies and in pregnancies associated with fetal dysmaturity. J. Obstet. Gynaec. Brit. Cwlth, 76, 127-130.

Klimek, R., and Bieniasz, A. (1969). Studies on the relation between serum oxytocinase and course of labour. Amer. J. Obstet. Gynec., 104, 959-963.

Kraussold, E., Wodrig, W., Sarembe, B. (1969). Die Serum-Isozitratdehydrogenase in der physiologischen Schwangerschaft und unter der Geburt. Zbl. Gynäk., 91, 1289-1291.

Lambrinopoulos, T. C. (1964). Prolonged pregnancy associated with increase in serum oxytocinase. Obstet. Gynec., 23, 780-782.

McMaster, Y., Tennant, R., Clubb, J. S., and Neale, F. C. (1964). The mechanism of the elevation of serum alkaline phosphatase in pregnancy. J. Obstet. Gynaec. Brit. Cwlth., 71, 735-739.

Meade, B. W., and Rosalki, S. B. (1963). Serum enzyme activity in normal pregnancy and the newborn. J. Obstet. Gynaec. Brit. Cwlth., 70, 693-700.

Messer, R. H. (1967). Heat-stable alkaline phosphatase as an index of placental function. Amer. J. Obstet. Gynec., 98, 459-465.

Neale, F. C., Clubb, J. S., Hotchkis, D., and Posen, S. (1965). Heat stability of human placental alkaline phosphatase. J. clin. Path., 18, 359-363.

Oakey, R. E., Bradshaw, L. R. A., Eccles, S. S., Stitch, S. R., and Heys, R. F. (1967). The rapid estimation of oestrogens in pregnancy to monitor foetal risk. Clin. chim. Acta., 15, 35-45.

Platt, D., and Platt, M. (1968). Hyaluronidase-, $\beta$-Glucuronidaseund $\beta$-Acetylglucosaminidase-aktivitat im menschlichen serum währende der Schwangerschaft. Klin. Wschr., 46, 768-771.

Pőch, G., Abad Martinez, L., Holzer, E., and Hohlweg, W. (1970).
Serum oxytocinase activity compared with HCG and oestriol during the third trimester of pregnancy. Arch. Gynäk., 208, 416.

Pulkkinen, M. O., and Willman, K. (1968). Enzymes and isoenzymes in maternal and fetal sera. Acta. obstet. gynec. scand., 47, 273-291.

Resnik, R., and Levine, R. J. (1969). Plasma diamine oxidase activity in pregnancy: a reappraisal. Amer. J. Obstet. Gynec., 104, 1061-1066.

Rimbach, E., and Figge, E. (1966). Serumproteine und cholinesterase während der Schwangerschaft im Anschluss an die Geburt und im Wochenbett. Zbl. Gynäk., 88, 1601-1607.

Rimbach, E., and Schreiner, R. (1967). Leucin-Aminopeptidase im Blutserum während der Gestation. Med. Welt (Stuttg.), 51, 3118-3120.

Southren, A. L., Kobayashi, Y., Carmody, N. C., and Weingold, A. B. (1966). Serial measurements of plasma diamine oxidase (DAO) during normal human pregnancy by an improved method. Evidence for the presence of a circulating DAO inhibitor. Amer. J. Obstet. Gynec., 95, 615-620.

Southren, A. L., Kobayashi, Y., Weingold, A. B., and Carmody, N. C. (1966). Serial plasma diamine oxidase (DAO) assays in first and second trimester complications of pregnancy. Amer. $J$. Obstet. Gynec., 96, 502-510.

Southren, A .L., Weingold, A. B., Kobayashi, Y., Sherman, D. H., Grimaldi, R., and Gold, M. (1968). Plasma diamine oxidase in pregnancy complicated by diabetes mellitus. Amer. J. Obstet. Gynec., 101, 899-908.

Székely, J. A., and Fritzsh, W. (1969). Die Serumaktivität der Transaminasen (SGOT, SGPT) und der Laktatdehydrogenase (SLDH) in der normalen Schwangerschaft und unter der Geburt. Zbl. Gynäk., 91, 1169-1174.

Torok, E. E., Brewer, J. I., and Dolkart, R. E. (1970). Serum diamine oxidase in pregnancy and in trophoblastic diseases. J. clin. Endocr., 30, 59-65.

Watney, P. J. M., Hallum, J., Ladell, D., and Scott, P. (1970). The relative usefulness of methods of assessing placental function. J. Obstet. Gynaec. Brit. Cwlth., 77, 301-311. 